Insect pests of legume and grass crops in western Canada

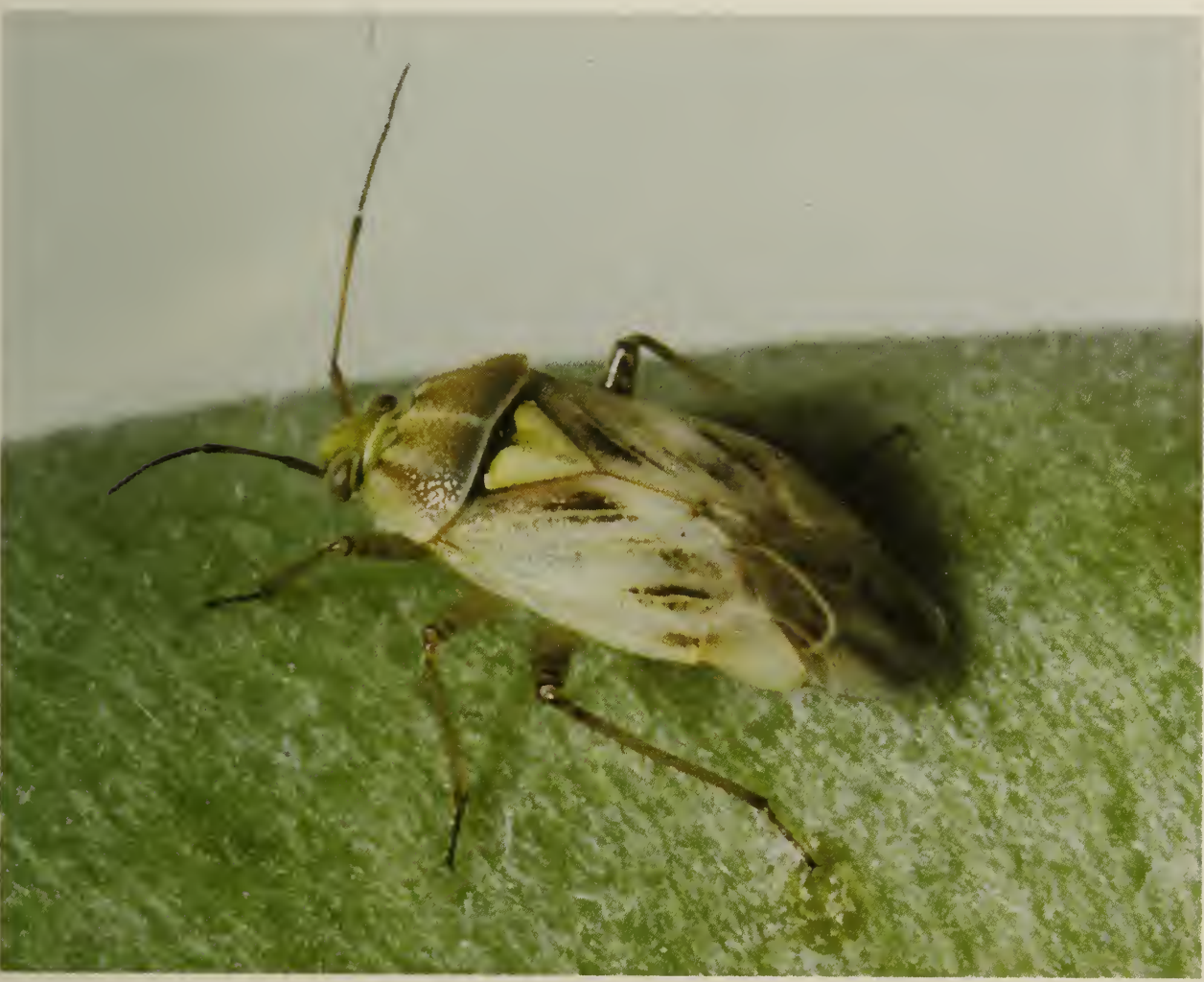


Digitized by the Internet Archive in 2013 


\title{
Insect pests of legume and grass crops in western Canada
}

\author{
Juliana J. Soroka
}

Research Station

Saskatoon, Saskatchewan

Recommendations for pesticide use in this publication are intended as guidelines only. Any application of a pesticide must be in accordance with directions printed on the product label of that pesticide as prescribed under the Pest Control Products Act. Always read the label. A pesticide should also be recommended by provincial authorities. Because recommendations for use may vary from province to province, consult your provincial agricultural representative for specific advice.

\section{Cover illustration}

An adult lygus bug, Lygus borealis (Kelton)

Agriculture Canada Publication 1435/E available from

Communications Branch, Agriculture Canada

Ottawa, Ont. K1A 0C7

๑ Minister of Supply and Services Canada 1991

Cat. No. A43-1435/1991E ISBN 0-662-19129-3

Printed 1971 Revised 1973 Reprinted 1989 Revised 1991 5M-12:91

Produced by Research Program Service

Également disponible en français sous le titre

Ravageurs des légumineuses et des graminées de l'ouest du Canada 


\section{Contents}

Acknowledgments 5

Summary of main insect pests 6

Integrated management of legume and grass pests 9

General insect pests 10

Grasshoppers 10

Cutworms 11

Insect pests of alfalfa 15

Plant bugs 15

Lygus bugs 15

Alfalfa plant bug 17

Pea aphid 18

Other legume aphids 19

Alfalfa weevil 20

Alfalfa seed chalcid 21

Alfalfa curculio 22

Webworms 23

Insect pests of sweetclover 24

Sweetclover weevil 24

Insect pests of red clover 26

Lesser clover leaf weevil 26

Clover thrips 27

Insect pests of white and alsike clovers 28

Clover seed weevil 28

Clover leaf weevil 28

Insect pests of grasses $\mathbf{3 0}$

Bromegrass seed midge 30

Grass plant bugs 31

Cereal aphids 32

Russian wheat aphid 32

Spittlebugs 33

European skipper 34

Grass thrips 35

Other pests of legume and grass crops 36

Beneficial insects 36

Precautions on the use of insecticides 38 


\section{Acknowledgments}

C. Harvey Craig wrote an earlier edition of this publication. The critical comments of the many people who reviewed this bulletin are greatly appreciated. Photo credits include M. Okuda for Plates $5 a, b$ and $6 b$; J.L. Harris for Plates $2 a, b$ and $5 f$; K.A. Pivnick for Plate $2 c$ and $f$; Agriculture Canada Lethbridge for Plates $5 e$ and $6 a$; and Washington State University for Plate $6 e$ to j. R.E. Underwood, Agriculture Canada, Saskatoon, took many of the photographs and compiled the plates. 


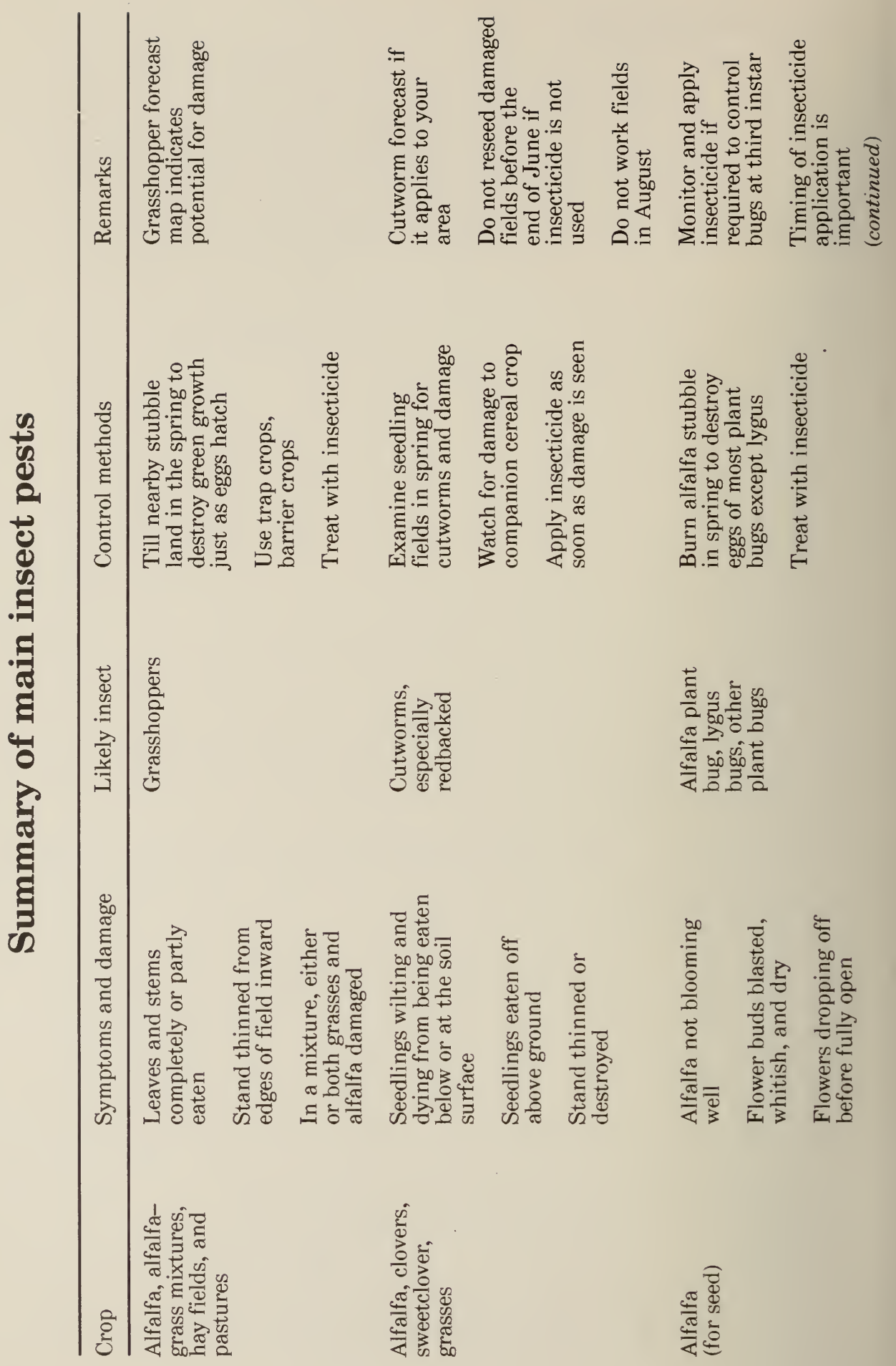




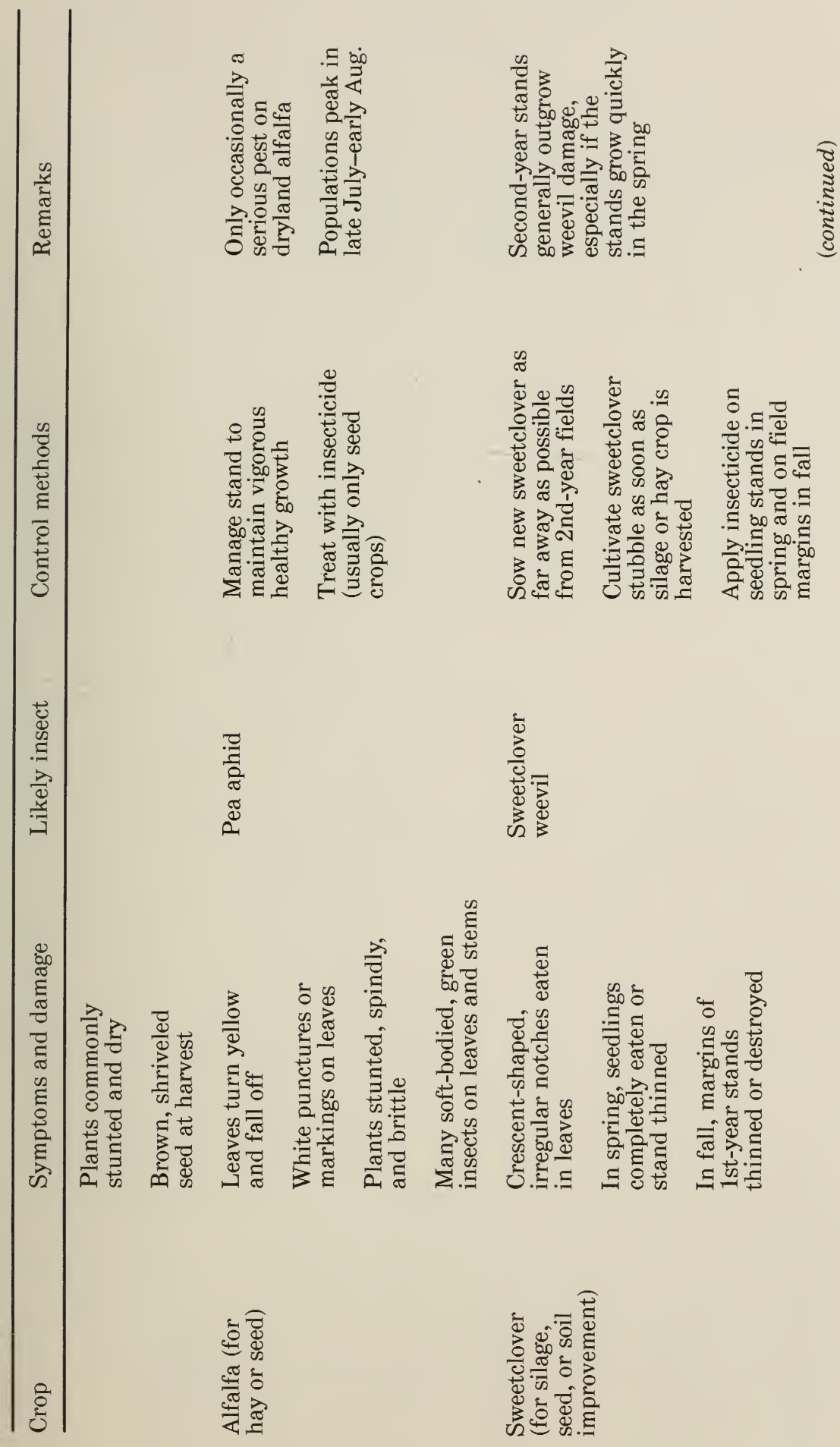




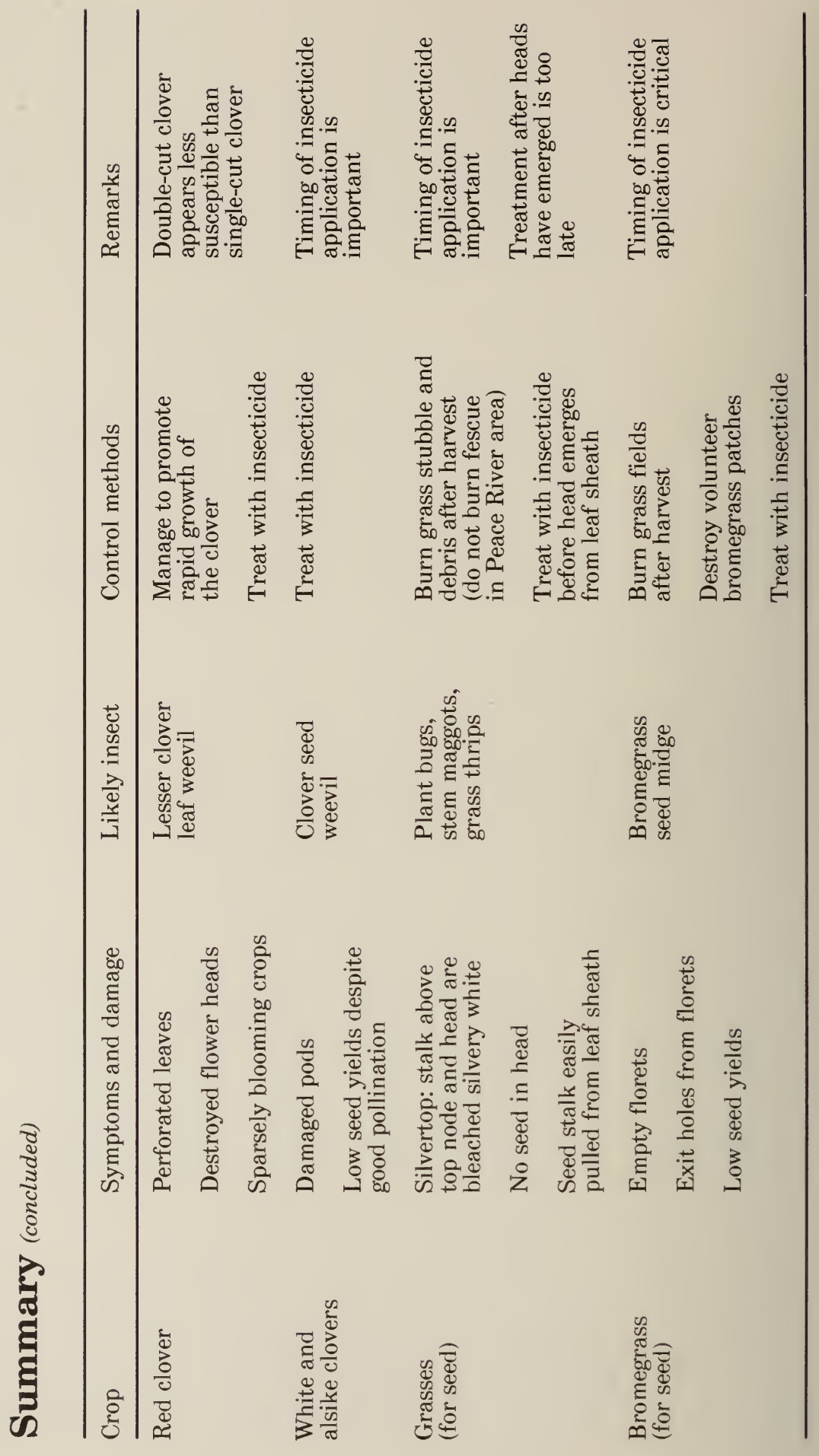




\section{Integrated management of legume and grass pests}

Integrated pest management is the timely use of various control strategies to decrease pest populations to below levels of economic injury while minimizing harmful effects on the environment. These control strategies are biological, cultural, and chemical in nature.

Beneficial insects play an important biological role in controlling pest species. Between them, beneficial insects, disease organisms, and inclement weather can destroy $50-90 \%$ of a pest population. Some of the most common and effective insects found in forage fields are listed under "Beneficial insects."

It is important for growers to know whether the insects in their crops are harmful or beneficial. Although insect identification may seem daunting at first, with practice growers soon learn to recognize the main pest and beneficial insect species in their fields. The easiest way to determine whether the populations are growing or declining is by sampling with a sweep net $38-\mathrm{cm}$ in diameter. Such a net can be either purchased or made from a hoop of heavy gauge wire $38 \mathrm{~cm}$ in diameter, a $0.6-\mathrm{m}$ dowel or broom handle, and a cotton bag about $50 \mathrm{~cm}$ deep, with an opening to fit over the hoop. Even sweeping the canopy with a cap is enough to indicate some of the insects present in a crop.

Take samples when conditions are calm, warm, and dry. Begin sampling when the crop nears a susceptible growth stage, such as at bud formation for alfalfa infested with lygus bugs. Plan to continue sampling weekly throughout the summer or until the susceptible stage of the crop has passed. Ideally, try to collect three or more samples throughout the field; there should be at least one sample per $2-4$ ha. The sampling unit is five sweeps of $180^{\circ}$, with about half of the net in the canopy (see Plate $6 b$ ). After each sweep move forward one or two steps until the five sweeps have been taken. Identify and count the insects or place them in plastic bags to be identified later by someone such as the local provincial agricultural representative. Some publications have stated economic thresholds of insects in numbers per $90^{\circ}$ sweep of a net. Doubling those numbers will approximate thresholds per $180^{\circ}$ sweep.

The following cultural practices help to control insect pest populations:

- weed control

- early spring and postharvest harrowing

- field burning

- cleanup and burning of trash and screenings in seed crops.

Avoid seeding hay fields next to seed fields and new stands near old ones.

Insecticides can control many pest insect populations; however, because they destroy beneficial species and pollinators, consider their use as a control method of last resort. Use insecticides only when field sampling indicates that economic damage to the crop by a pest insect is imminent. Often, environmental conditions leading either to the rapid buildup of diseases or parasites of the pest, or to the rapid growth of the crop, may 
decrease potentially damaging numbers of a pest to below the economic threshold. Chemicals may be the control measure of choice when pest numbers explode rapidly and unexpectedly. Alternative strategies, such as crop rotation or the use of less susceptible crops, are more appropriate when a pest insect presents a chronic problem in an area.

\section{General insect pests}

\section{Grasshoppers}

Description The four major species of grasshoppers in western Canada are the clearwinged (Camnula pellucida (Scudder)), twostriped (Melanoplus bivittatus (Say)), migratory (M. sanguinipes (Fabricius)) (Plate 1e), and Packard (M. packardii Scudder) grasshoppers. The species have different host preferences; clearwinged grasshoppers are more frequently associated with grasses than with forage legumes. Usually several grasshopper species can be found in most legume and grass seed crops, forage fields, and rangelands. The species vary in size, coloration, and habits but all cause the same type of crop damage. Young grasshoppers or nymphs resemble adults, except that they are smaller and do not have wings.

Life cycle Most species of grasshoppers in western Canada overwinter as eggs laid below the soil surface in protective pods containing 10-100 eggs. The eggs start hatching in late spring or early summer. Newly emerged nymphs are 3-4 mm long. As they grow they molt five times; the stages of development between molts are called instars, so grasshoppers develop through five instars. They become adults in July. Mating and egg laying continue until the end of the season. Hot, dry weather increases not only the rate at which grasshoppers develop but also crop susceptibility to feeding injury. Twostriped, migratory, and Packard grasshoppers lay eggs throughout fields and along ditch banks and fence lines, dispersing their eggs to varying degrees. Clearwinged grasshoppers lay eggs in beds in sparsely vegetated pastures, fence lines, headlands, and along roadsides. Grasshoppers deposit egg pods in late summer and fall and have only one generation per year. Some rangeland grasshoppers overwinter as nymphs or adults. When these become active in the spring, false reports may circulate that the main hatch has begun.

Damage Alfalfa and grass in hayfields, pastures, and on rangeland can be damaged extensively by grasshoppers feeding on leaves, buds, flowers, and seed pods (Plate $1 f, g$ ). Severe crop damage may occur when the foliage is short and sparse. Grasshoppers that emerge from egg beds outside the fields injure the plants from the field margins inward; those that emerge from eggs laid within the fields feed throughout the crop. Grasshoppers emerging from rangeland egg beds occasionally migrate into adjacent crops and cause considerable damage. Grasshoppers do not usually invade a lush, 
established alfalfa stand because of the higher humidity and lower temperatures within the canopy. However, alfalfa seed fields can be attacked in late summer by grasshoppers invading either from adjacent grain and hay fields that have been harvested, from pastures when grasses become dormant, or from summerfallow after weeds have been controlled. Grasshoppers can destroy an alfalfa seed crop in late summer by stripping the seed pods (Plate $1 f$ ).

Control Some provincial agricultural departments issue grasshopper forecast maps annually. These maps predict the extent and severity of the grasshopper infestations for the coming season. Predictions are updated as the overwintering survival of eggs is determined. The severity of the actual grasshopper infestations depends mainly on weather. Warm, dry weather in early summer enhances nymphal survival and increases the likelihood of damage to crops.

Eliminating annual weeds by applying herbicide or by cultivating in spring reduces numbers of emerging grasshoppers by destroying their food supplies, which greatly reduces the threat of crop damage. Grasshoppers may be deterred from invading established fields by planting nonpreferred crops such as oats in strips $10 \mathrm{~m}$ or wider around the field perimeter to act as barriers. Applying insecticide to field edges may be all that is necessary to reduce numbers of invading grasshoppers. Alternatively, plant a preferred crop such as fall rye around the field edge; then a carefully timed application of insecticide to this trap crop can control the outbreak. Applying insecticide as bran bait rather than as foliar spray lessens the hazard of the insecticide to pollinators and many other nontarget species.

The potential for crop losses due to grasshoppers depends upon the numbers of grasshoppers in the field, the growth stage of both the crop and the grasshoppers, and weather conditions. Usually, infestations of less than about 10 grasshoppers per square metre do not cause losses to forage fields. A small, heat- or drought-stressed plant suffers greater injury from grasshopper feeding than a large, vigorous plant growing under favorable weather conditions. If the duration of egg hatch is prolonged and grasshopper numbers reach damaging levels, more than one application of insecticide may be needed for adequate control.

\section{Cutworms}

Cutworms (Euxoa spp., Agrotis spp., and others) are periodic pests of legumes, grasses, and a variety of other crops in western Canada. Some, such as the army cutworm (Euxoa auxilliaris (Grote)), feed above ground, whereas others, such as the redbacked ( $E$. ochrogaster (Guenée)) (Plate $2 \mathrm{~g}$ ), and the pale western (Agrotis orthogonia Morrison) cutworms, feed at or below the soil surface. The larvae and adults are most active during the late evening or at night and are seldom seen. Adult cutworm moths are often attracted to lights. 

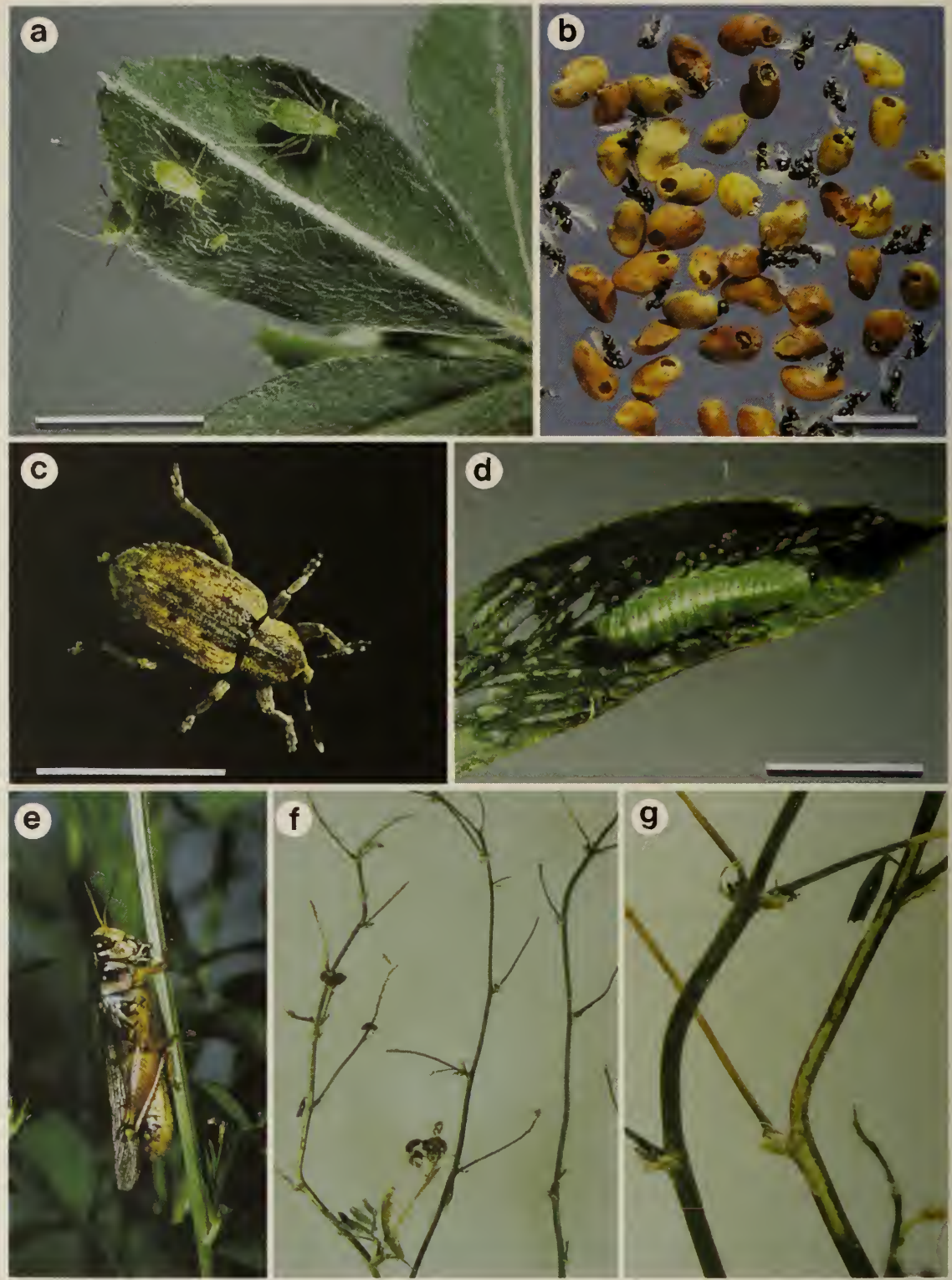

Plate 1 $a$. Pea aphids on an alfalfa leaf $b$. Alfalfa seed infested with alfalfa seed chalcids; note chalcid exit holes in the seed $c$. Adult alfalfa weevil $d$. Late-instar alfalfa weevil larva on a skeletonized alfalfa leaf $e$. Adult migratory grasshopper $f$. Alfalfa stems damaged by grasshopper; note stripping of seed pods $g$. Closeup of alfalfa stems, showing "barking" or stripping of outer cells. (Scale: bar $=4 \mathrm{~mm}$ ) 


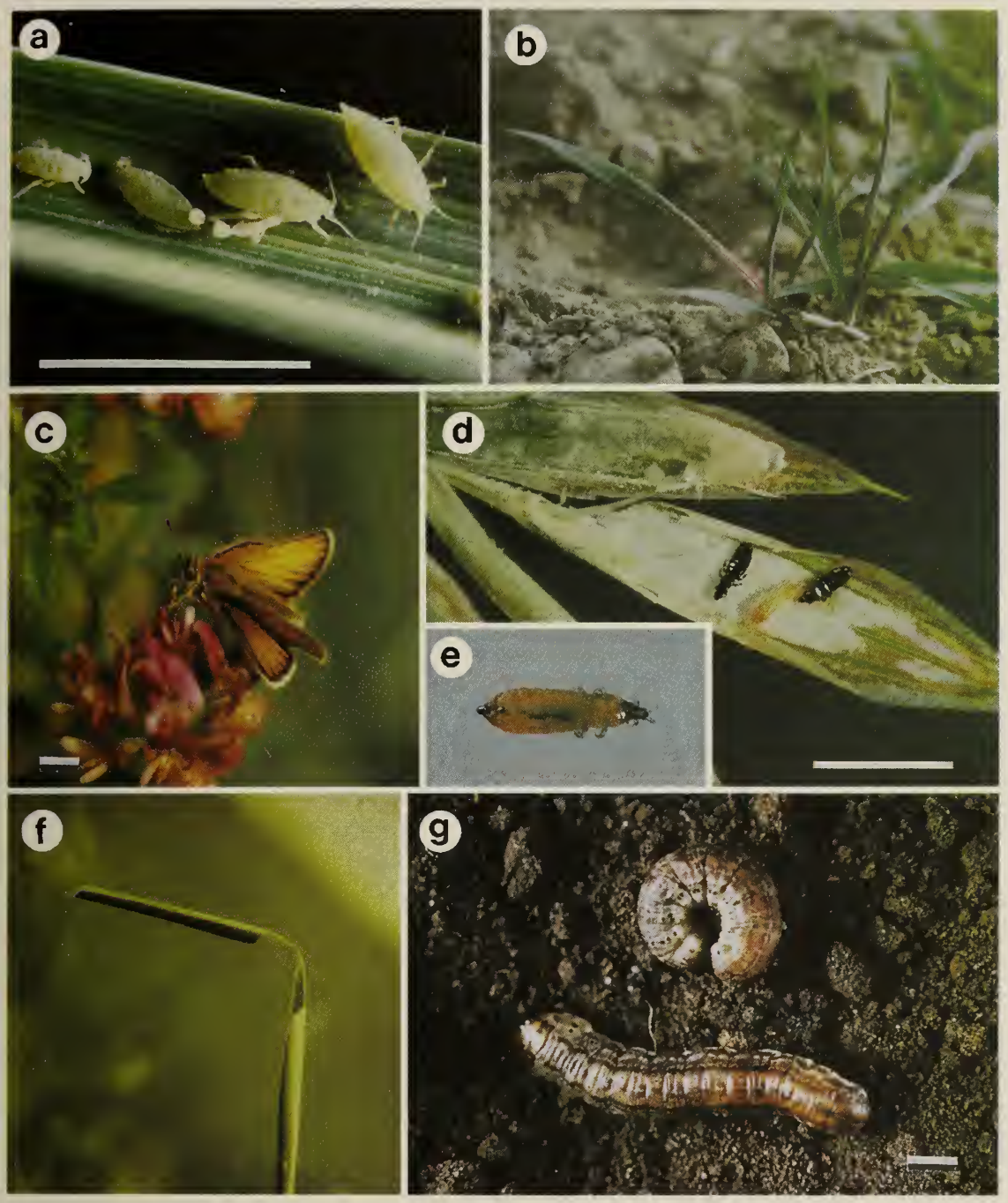

Plate $2 a$. Russian wheat aphid adults and a nymph $b$. Wheat plant injured by Russian wheat aphid; note the purple streaking and curling of the leaves $c$. European skipper adult on an alfalfa flower $d$. Two adults and a nymphal grass thrips in a bromegrass floret $e$. A grass thrips nymph $f$. Timothy blade showing leaf roll containing European skipper larva and feeding injury $g$. Redbacked cutworm larvae. (Scale: bar $=4 \mathrm{~mm}$ ) 
Description Cutworm adults are moths with dark gray, brown, or reddish forewings, marked with bands, spots, or mottled areas, and with paler hind wings. Their wingspans vary from 25 to $40 \mathrm{~mm}$. The larvae are smooth-skinned caterpillars, pale greenish gray to brown and $20-40 \mathrm{~mm}$ long at maturity; some species have stripes along their sides or backs.

Life cycle Most of the economically important species have only one generation each year. Cutworms overwinter as eggs, larvae, or pupae, depending on the species. The army cutworm overwinters as a partly grown larva. It feeds on weed growth in the early spring and then moves onto crop plants as these develop. Army cutworms may migrate in masses from uncultivated areas into forage fields after weed growth is depleted or after cultivation. Other species such as the redbacked and pale western cutworms overwinter as eggs. Cutworm larvae pass through six or seven molts and pupate in earthen cells in the soil. Adult moths emerge in late summer and lay eggs on foliage or near the soil surface. Depending on the species, egg hatch occurs in the fall or spring. Army cutworm eggs hatch in the fall; the larvae feed until freeze-up. Dry spring weather favors the survival of most cutworms. Wet weather in the fall promotes the growth of weeds and the survival of army cutworm larvae.

Damage Cutworms sever young plants at the soil surface. The foliage of established plants may occasionally be severely damaged by above-ground feeding. Wilted, severed, or missing plants or plants with severe defoliation are characteristic of cutworm injury. Companion crops can also be damaged.

Control Cutworms are usually controlled by weather or by natural enemies, including parasites, predators, or diseases. Cutworm forecasts indicate the potential severity of these pests in certain areas, but the forecasts are not accurate enough to predict damage in particular fields. If the forecast indicates a potential for cutworm damage, cultivating fields early in the spring and delaying seeding of these fields for at least 2 weeks occasionally helps to reduce cutworm damage to crops. If fields damaged by either pale western or redbacked cutworms are cultivated, do not reseed them before late June unless an insecticide is applied immediately after reseeding. Destroy weed growth in summerfallow fields during late July and allow the fields to crust over, because several cutworm species prefer to lay their eggs in fields that are either weedy or have loose soil. If extensive damage to crops is detected and cutworms have been identified as the cause, insecticide control is effective. Insecticides for cutworm control work best if applied in late evening, when the cutworms are active. If the upper 5-8 cm of soil are dry, insecticide control may be less than adequate. Spray only the infested areas in fields. 


\section{Insect pests of alfalfa}

\section{Plant bugs}

Many kinds of plant bugs (Lygus spp., Adelphocoris spp., and others) are present in alfalfa fields. They are rarely of importance in alfalfa or alfalfa-grass mixtures grown for hay, silage, dehydration, or pasture. However, lygus bugs and the alfalfa plant bug are serious pests of alfalfa grown for seed.

\section{Lygus bugs}

Several species of lygus bugs are found in alfalfa fields across western Canada. One of the most widespread of these is the tarnished plant bug (Lygus lineolaris (Palisot de Beauvois)).

Description Adult lygus bugs are 4-6 $\mathrm{mm}$ long and vary in color from pale green to reddish brown (Plate $3 a, c$ ). They have a distinct light-colored triangle in the upper middle area of their backs. Young lygus nymphs resemble pea aphids but are more active. Older nymphs develop wing buds and have several, usually five, prominent black spots on their backs.

Life cycle Lygus bugs overwinter as adults under plant debris at the soil surface in uncultivated areas and field margins. They become active and reenter alfalfa fields as temperatures rise in spring. Females lay eggs in alfalfa stems; the nymphs, which emerge from the eggs from the end of May until mid July, molt five times and take about 1 month to mature. In late summer, new adults migrate from other host plants into late-maturing alfalfa seed fields. Adults disperse from alfalfa to other host plants and overwintering sites during the fall. Two generations of lygus bugs can occur in southern Canada. The first generation develops between April and mid July, the second between mid July and September. In northern areas, lygus bugs move into the alfalfa during May and early June, and development of the single generation is complete by mid August.

Damage Both nymphal and adult plant bugs of all species feed by piercing the plant tissue with their needle-like mouthparts and sucking plant sap. They feed on flower buds, flowers, and developing seeds. Older instars cause more injury to alfalfa plants than do adults because they are more active feeders. Although they do injure buds, lygus bugs most often injure flowers and young seeds. Flowers fed upon by lygus bugs may suddenly wilt and drop off (Plate $3 e$ ), and seeds (Plate $3 f$ ) may become distorted, shrunken, dark, and nonviable (Plate $3 g$ ), thereby greatly reducing seed yield. Lygus-damaged seed is often not evident because it is not retained during combining.

Control Burning of alfalfa in the spring before the onset of plant growth can destroy any lygus adults present in the fields. However, lygus bug populations can rapidly increase and, as adults, reinfest alfalfa fields after 

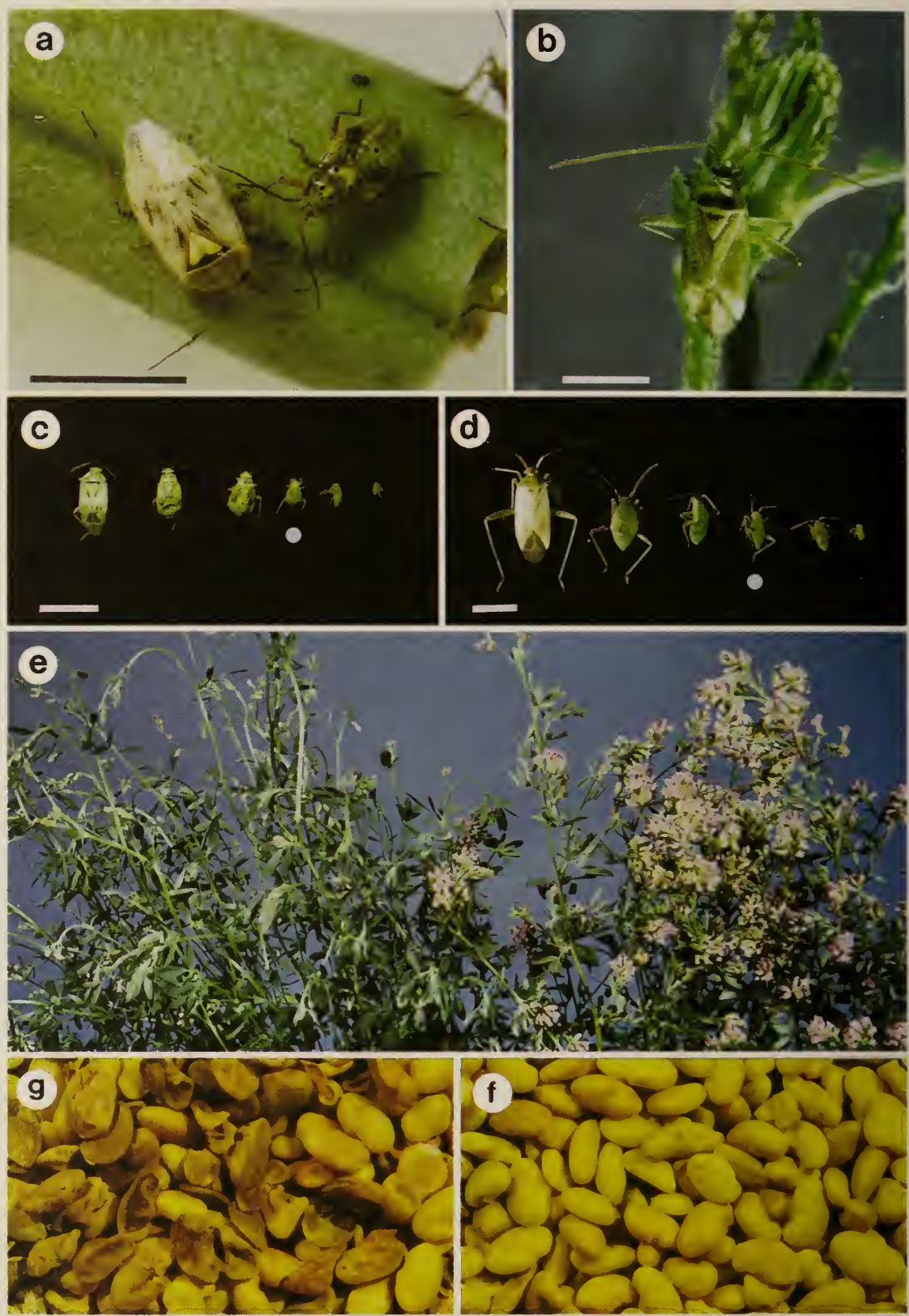

Plate $3 a$. Adult and fifth-instar lygus bugs $b$. Adult alfalfa plant bug $c$. Adult and five lygus bug instars; insecticide control is aimed at the third-instar nymph (indicated), which is just developing wing buds. $d$. Adult and five instars of alfalfa plant bug; third-instar nymph, at which insecticide application is aimed, is indicated $e$. (left) Alfalfa injured by lygus bug feeding, showing flower loss; (right) healthy alfalfa $f$. Healthy alfalfa seed $g$. Alfalfa seed injured by lygus bug feeding. (Scale: bar $=4 \mathrm{~mm}$ ) 
burning. Use insecticides only if plant bug numbers surpass levels that cause economic injury, for otherwise the benefits of control will not outweigh its costs. If numbers warrant insecticide treatment, apply it to coincide with the third-instar nymphs (Plate 3c) so that control can be achieved before the more damaging later instars and adults occur. Weekly sweep-net sampling of alfalfa seed fields from the flower bud stage to the dough stage of seed maturation is needed to determine the potential of plant bugs to cause yield losses.

The economic threshold is five lygus bugs per $180^{\circ}$ sweep of the net at bud formation and flowering. Adult lygus bug populations of one bug per two sweeps early in the spring have the potential of reaching economic thresholds by the time of flowering if they are not controlled naturally. In northern regions, where there is only one generation of lygus or other plant bugs per year, one application of insecticide in June just before leafcutting bees are set out will control the bugs for the entire season. In southern regions where there are two generations of plant bugs per year, monitor alfalfa fields during late July or early August as well as at bud to see if numbers warrant a second application of insecticide. Economic thresholds at this time of year are 10 lygus bugs per sweep. Lygus bugs may reinfest alfalfa fields as surrounding crops such as canola are swathed; if alfalfa seed pods are still very young, late-season control of the insects may be necessary. If insecticide has to be applied while alfalfa and surrounding crops are flowering, apply selective insecticides that are the least toxic to pollinators only when the bees are not foraging (see "Precautions on the use of insecticides" Table 1).

\section{Alfalfa plant bug}

The alfalfa plant bug (Adelphocoris lineolatus (Goeze)) is common across the Prairie Provinces, especially in parkland areas, but is less common in British Columbia.

Description Alfalfa plant bug adults are slightly longer and larger than lygus bugs, being 8-9 $\mathrm{mm}$ long and yellowish green to dark green (Plate $3 b, d)$, with a triangle on their backs that is less distinct than on lygus adults. The last antennal segment of the nymphs is enlarged and darker than other segments. The nymphs do not have spots on their backs.

Life cycle The alfalfa plant bug overwinters as an egg in stubble and harvest debris. The egg hatch starts near the end of May and is usually complete by mid June. Rates of growth and development depend upon temperature, but nymphs molt five times and take up to 30 days to become adults. About the middle of July, 2 weeks after becoming adults, female alfalfa plant bugs deposit their eggs in the hollow stems of growing alfalfa. In the southern prairies, two generations a year can occur. In northern areas the eggs laid by the first generation of adults usually remain in the stems until the following spring, but a second generation can occur when spring temperatures are very warm and when the first generation develops very rapidly. 
Damage Because alfalfa plant bugs attack mainly buds and young flowers, the greatest damage by this species is bud-blasting, wherein buds shrivel, turn grayish white, and die. A heavily infested field has few flowers, and, if plant bug numbers are very high, there may be no bloom at all.

Control Early spring burning of alfalfa stubble and debris destroys alfalfa plant bug eggs and reduces the numbers of plant bugs that overwinter as adults in the fields. Spring burning also aids in destroying alfalfa disease inoculum in the fields; however, because it destroys soil organic material, burning is recommended only every 2 nd year instead of annually. If necessary, apply insecticide when alfalfa plant bugs have become third-instar nymphs (Plate $3 d$ ). The economic threshold is four alfalfa plant bugs per sweep at the flower bud stage and eight at the seed stage.

If both alfalfa plant bug and lygus bugs are present, the economic threshold is five bugs per sweep at flowering. Apply insecticide slightly later in the year than for alfalfa plant bugs alone. Thus, while alfalfa plant bugs will be fourth- and fifth-instar nymphs at the time of spraying, most lygus bugs might be third-instar nymphs. Spraying earlier than this may not kill late-hatching lygus nymphs.

\section{Pea aphid}

Description Pea aphids (Acyrthosiphon pisum (Harris)) are small, light green insects with soft, pear-shaped bodies (Plate 1a). Adults may be winged or wingless and can reach $3 \mathrm{~mm}$ in length. The four nymphs resemble the wingless adult. Young pea aphids resemble young plant bugs but can be easily distinguished by their much slower movements and by two small projections called cornicles on their posterior abdomen.

Life cycle Pea aphids overwinter as eggs on alfalfa on the Canadian prairies. In the spring, all young are wingless females. At maturity these give birth to living young without mating and have several generations of wingless females per season. When the aphids become crowded or when the host plants are no longer suitable, winged forms develop that disperse to other alfalfa fields or to annual legumes. In late spring, pea aphids migrate into Canada from the United States on air currents. Aphid populations can build rapidly because time from birth to reproduction can be as short as 6 days under ideal conditions and each aphid can give birth to 100 or more young. Pea aphid populations usually peak in late July or early August. In the fall, winged males and wingless females are produced. After mating, the females lay the overwintering eggs.

Damage Aphids feed by piercing plant tissue and sucking plant sap. Heavily infested plants exhibit symptoms such as wilting, yellowing, and dropping of leaves and stunting of growth. Heavily infested stems may become spindly and brittle. Tops of plants may die, which results in reduced yield and quality of hay. In seed crops flowering may be reduced, and there may be a great loss of flowers. This aphid can also transmit verticillium wilt disease, and large numbers can reduce winter hardiness of alfalfa. Pea 
aphids are occasionally a pest of dryland alfalfa produced for forage when large infestations develop locally. Alfalfa under drought stress, especially second-cut alfalfa, is most susceptible to injury. Because moist, warm weather favors aphid growth, populations of this insect are often greater in irrigated than in dryland alfalfa. However, the lush growth of irrigated alfalfa can support greater numbers of aphids without apparent injury.

Control Predators, parasites, and diseases generally hold infestations of pea aphids in alfalfa at low levels. Weather conducive to the rapid growth of alfalfa decreases the risk of crop damage from pea aphids. Aphids grow and develop more slowly in very hot or very cold weather. Heavy rains and strong winds may dislodge and kill many aphids. In dryland production, aphid numbers greater than $100-200$ per $180^{\circ}$ sweep can cause significant injury to alfalfa. Under irrigation, however, aphid numbers of more than 1400 per sweep were found not to reduce alfalfa forage yields. Vigorous, thick, healthy stands of forage alfalfa are the best safeguard against damage by pea aphids. Early cutting of alfalfa for forage curtails aphid population growth and usually avoids the use of insecticides. If plant injury caused by pea aphids is seen in seed fields, apply a recommended insecticide.

\section{Other legume aphids}

The following legume aphids damage legume crops in western Canada:

- spotted alfalfa aphid (Therioaphis maculata (Buckton))

- yellow clover aphid (Therioaphis trifolii (Monell))

- sweetclover aphid (Therioaphis riehmi (Börner))

- clover aphid (Nearctaphis bakeri (Cowen))

- blue alfalfa aphid (Acyrthosiphon kondoi Shinji).

Description The three Therioaphis species are yellowish brown with varying numbers of dark spots on their backs. The clover aphid is a light green or pinkish green aphid, whereas the blue alfalfa aphid is slightly smaller than the pea aphid and more blue.

Life cycle Like the pea aphid, these species rapidly build up high populations under favorable conditions by giving birth to live young and by generating winged forms that disperse when hosts or environmental conditions become unsuitable.

Damage These aphids injure plants by sucking plant sap in the same way as does the pea aphid. However, the spotted and blue alfalfa aphids also inject a toxin into the plants as they feed, which causes severe stunting and yellowing of the entire plant. Leaves drop off from the ground up, and heavily infested plants may die. Seedling alfalfa fields may be completely destroyed, and surviving plants take considerable time to recover. Forage yields can be drastically reduced. As their common names indicate, the species vary somewhat in their host preferences. 
Populations of yellow clover and sweetclover aphids generally do not reach damaging levels. The clover aphid has occasionally been plentiful on red and alsike clovers grown for seed in the lower Fraser Valley of British Columbia. The spotted alfalfa aphid was first found on the prairies in the early 1980s. Although numbers appear to be increasing, damage to alfalfa by this pest has not been reported in Canada. However, it causes serious losses to alfalfa forage in the United States. The blue alfalfa aphid is a recent introduction into North America and has become well established in the American midwest. Because it now occurs in states bordering Canada, it is a potential threat to western Canadian alfalfa production.

Control Many of the predators, parasites, and diseases of the pea aphid also attack other legume aphids. As they adapt to the new aphid hosts, these natural control agents may become important in controlling the new pests. Some recently licensed cultivars of alfalfa are resistant to aphids. Most of the insecticides registered for control of pea aphid will also control other species of aphids.

\section{Alfalfa weevil}

The alfalfa weevil (Hypera postica (Guyllenhal)) is one of the most serious insect pests of alfalfa in eastern Canada and the United States. In western Canada it has caused crop losses in southeastern Alberta and southwestern Saskatchewan.

Description The adult alfalfa weevil is a small, robust, nocturnally active snout beetle about $5 \mathrm{~mm}$ long (Plate 1c). Adults emerging from overwintering sites are silvery brown with a darker brown stripe down the centre of their backs. As adults age the silvery scales are lost, and their bodies appear to darken. The caterpillar-like larvae are about $1 \mathrm{~mm}$ long when they hatch. The first, second, and early third instars are yellowish white with a black head. The late third- and fourth-instar larvae are bright green with a prominent white dorsal stripe and a brown head (Plate 1d). Full-grown larvae reach a length of $9 \mathrm{~mm}$.

Life cycle Adults overwinter in the crowns of alfalfa plants, in plant debris, and in the soil of field borders. Soon after they become active in the spring, they mate and the females insert their eggs in old alfalfa stems and ground litter, and later, in the stems of new growth. Several hundred eggs are deposited in clusters by each female. Larvae emerge in about 2 weeks and crawl to the tips of the plants, where they feed inside the leaf and flower buds. Older larvae feed on the foliage. The larvae molt four times, reaching maturity in 2-4 weeks; their peak feeding activity extends from mid June to mid July. Full-grown larvae drop to the ground, spin net-like cocoons in the litter, and pupate. Adults emerge 1-2 weeks later, feed on the plants for about 2 weeks, and then disperse from the fields and become dormant for the summer. They resume activity in late summer when they feed for a short time before hibernating. There is one complete generation a year in western Canada. 
Damage Both adults and larvae feed primarily on alfalfa. Adults shred the leaf margins and chew on stems and new shoots, but such damage is rarely important. In late spring and early summer, the young larvae feed inside leaf buds and unopened racemes. Older larvae skeletonize the leaves (Plate $1 d$ ). In heavily infested fields, growing tips may be completely eaten and growth may be stunted; severely damaged fields take on a grayish white cast likened to frost-injury. Alfalfa weevils can be especially damaging to seedling stands of alfalfa or alfalfa grown for seed. Yield and quality of alfalfa hay, especially first-cut alfalfa, can also be greatly reduced and the regrowth damaged. Alfalfa grown under irrigation or when soil moisture levels are high is better able to tolerate alfalfa weevil injury than alfalfa grown under dry conditions.

Control Although burning of alfalfa fields after growth has started in the spring delays bloom, it also reduces overwintering weevil populations. Damage to hay crops can also be reduced by growing dense, vigorous stands. Early cutting of hay fields reduces alfalfa weevil numbers, as will green chopping of the crop. If more than $25 \%$ of stems have feeding injury at the tips, cut and remove the crop as soon as possible. A field free of crop debris deprives larvae of food and shelter and exposes them to the sun and to predators. If early cutting is not possible, and if there are more than five or six larvae per stem, insecticide may need to be applied, especially if larval populations are increasing rapidly. Economic thresholds for alfalfa weevil in seed fields have not been developed for western Canada, but insecticides may be necessary if there are more than $10-13$ larvae per $180^{\circ}$ sweep or if more than $35 \%$ of foliage tips show damage. There are many natural enemies of alfalfa weevil, including a fungus disease and insect parasites and predators. Some of these have been introduced from eastern Canada and Europe, where they aid in controlling alfalfa weevil populations. Therefore, consider the detrimental effects of insecticides on these beneficial insects. Some alfalfa cultivars are more susceptible to weevil damage than others. The true clovers are rarely injured by weevil feeding but may be damaged in mixed stands. Sainfoin appears to be immune.

\section{Alfalfa seed chalcid}

Description The adult alfalfa seed chalcid (Bruchophagus roddi (Gussakovsky)) is a small wasp 1.5-2.5 mm long, metallic black in color, with dark brown legs (Plate $1 b$ ). The tiny, white, maggot-like larva feeds within ripening alfalfa seeds. The clover seed chalcid (Bruchophagus gibbus (Boheman)), the trefoil seed chalcid (Bruchophagus platypterus (Walker)), and the sainfoin seed chalcid (Eurytoma onobrychidis Walker) appear similar to the alfalfa seed chalcid; they cause similar damage to seeds but feed on different plants.

Life cycle Mature larvae overwinter in seeds in the fields. They emerge as adults when alfalfa begins to flower the next year. Females lay their eggs inside soft, developing seeds. Larvae emerge from the eggs and feed inside 
the developing seeds; they then pupate inside the hollowed out seed coat. The larvae complete their growth in about 2 weeks. After a short pupation, the summer generation of adults chews its way out of the seed and lays eggs in developing green pods. These eggs hatch to produce the overwintering generation of larvae. Because adults have a protracted period of emergence, all stages of the alfalfa seed chalcid are present throughout the summer.

Damage Seed chalcids do not affect production of alfalfa forage but can cause considerable damage to alfalfa grown for seed. Although adults cause only superficial injury to pods, larvae feed in the developing seeds and usually destroy them completely, leaving empty shells (Plate 1b). Broken or cracked seeds and seed pods with holes in them indicate injury by alfalfa seed chalcids. At harvest, seed chalcid damage to a seed crop may go unnoticed, for damaged seeds are blown out with the straw. More than 50\% of the seeds in a crop can be damaged. Damage to crops in dryland areas can be twice that in irrigated areas.

Control Control volunteer alfalfa and clovers before they set seed. Shallow cultivation of seed fields in the fall or spring buries many chalcid-infested seeds. Destroy the combine tailings and screenings, because they can contain infested seed. Burn stubble and straw soon after harvest, before regrowth has begun. When seeding, do not broadcast infested seed for this may result in chalcids surviving and proliferating. Carefully examine uncertified seed prior to planting for signs of chalcid damage. Whenever possible sow certified seed.

\section{Alfalfa curculio}

Description Adult alfalfa curculios (Sitona scissifrons Say) are 2-4 mm long, grayish brown snout weevils that resemble the sweetclover weevil (Plate $4 b$ ) but are somewhat smaller. The larvae resemble larvae of the sweetclover weevil.

Life cycle The biology of the alfalfa curculio is not well known but is probably similar to that of the sweetclover weevil. Adults overwinter under debris and begin to feed and mate as temperatures rise in the spring. Eggs are laid on the ground near the base of plants during May and June and hatch about 3 weeks later. Larvae molt four times and pupate in the soil. Adults emerge in late July and early August, feed for a time, and then seek overwintering sites.

Damage Adults feed on foliage of alfalfa, sainfoin, and vetch, chewing characteristic notches in leaves. Seedling stands of alfalfa or sainfoin can be destroyed. Established stands are generally resistant to foliar damage. However, adult feeding on developing shoots of cicer milk-vetch at the soil surface can delay shoot emergence in the early spring. Young-instar larvae feed in root nodules and hairs, whereas older instars feed externally on 
roots. Such feeding can increase the incidence of infection by plant diseases, which in turn decreases the vigor of the stand.

Control Growers of sainfoin and cicer milk-vetch should monitor their fields closely in the spring to check shoot emergence. If there is feeding damage to crowns of established plants before they emerge, or if seedlings are being destroyed, insecticide may need to be applied. For established stands, once the vegetation appears above ground, the critical period of injury is past.

\section{Webworms}

Several species of webworms (Loxostege spp. and garden webworm, Achyra rantalis (Guenée)) can occur in large numbers in alfalfa fields. They have some similarities in appearance and life cycle. The alfalfa webworm (Loxostege cereralis (Zeller)) has caused economic injury to alfalfa seed fields in Saskatchewan.

Description Adults are small, buff, grayish brown or brownish moths with a wing span of about $18 \mathrm{~mm}$. During the day they often fly up in large numbers when disturbed in crops and along roadsides. The greenish or yellowish caterpillars can reach $25 \mathrm{~mm}$ in length and have black spots or two bands of stripes on each side of the back.

Life cycle Webworms overwinter as larvae in silken cocoons in the soil and pupate in late spring. Adult moths lay eggs on the undersides of leaves of food plants; these eggs soon hatch and the tiny worm-like larvae begin feeding. When garden webworm larval numbers are high the larvae enclose themselves in webs, which may completely envelope the plant. The larvae pupate in the soil for about 3 weeks, and adult moths emerge 1 week later. There may be more than one generation per year, depending on locality and seasonal temperature.

Damage Larvae defoliate plants and, if numbers are high enough, they may completely destroy a crop. While feeding, the larvae enclose themselves in webs, which may completely envelop the defoliated plant if larval numbers are high. Seedling crops are more vulnerable to damage than established stands, which often quickly outgrow injury. Larvae feed on a variety of plants. Alfalfa webworm larvae prefer alfalfa, whereas the larvae of beet webworm (L. sticticalis (Linnaeus)) prefer Russian thistle, lamb's-quarters, kochia, canola, and flax. High populations of larvae and moths in spring can lead to a severe outbreak in midsummer. The volume of larvae and their droppings can foul cutting equipment and make cutting of hay crops difficult.

Control Destroying weeds early in the season helps to keep webworm numbers low. Early cutting of hay fields kills many of the larvae. If damage is evident in seedling stands, chemical control may be warranted. Aim to control early instar larvae, before extensive webbing occurs on the foliage. 


\section{Insect pests of sweetclover}

\section{Sweetclover weevil}

The sweetclover weevil (Sitona cylindricollis Fåhraeus) is the main pest of sweetclover wherever the crop is grown in North America.

Description Adult sweetclover weevils are dark gray to brown snout beetles about $5 \mathrm{~mm}$ long (Plate $4 b$ ). They are most active in the evening or at night, which, coupled with their habit of dropping to the ground when disturbed, makes them difficult to detect. The grub-like larvae are small and white.

Life cycle Adults overwinter in crop debris or soil cracks in sweetclover fields. They resume activity early in the spring, feeding on emerging sweetclover plants. As temperatures increase, they may fly to newly seeded sweetclover fields. Mating and egg-laying begin about mid May. Eggs are deposited at the soil surface, and newly emerged larvae burrow into the soil to feed on clover roots. They pupate near the soil surface. Adults start to emerge about the 2nd week in August. This new generation of adults does not fly before winter but disperses by walking. Movement and feeding activity continues until cold weather causes the weevils to seek overwintering sites.

Damage Adult sweetclover weevils chew jagged, crescent-shaped notches in the leaves of sweetclover (Plate $4 a$ ). In dry years, when new stands are difficult to establish and growth is slow, seedlings are commonly injured as they emerge from the soil, and fields may be completely destroyed. When 2nd-year clover stands are cut or harvested for seed, weevils can invade nearby 1st-year stands, causing characteristic damage to field margins (Plate 4c). Partially defoliated plants may not overwinter successfully. Second-year stands are usually capable of outgrowing sweetclover weevil damage, but a very heavy infestation early in a dry year can severely stunt and thin a crop. Adult weevils will feed on green seeds if no foliage is available, but they do not damage ripe seed. Larval feeding on root nodules and root hairs increases the susceptibility of roots to root rot, which can result in severe winterkill.

Control Economic thresholds in seedling sweetclover crops are one adult weevil per 3-5 seedlings in the cotyledon stage, depending on growth conditions, and 9-12 adults per plant in newly emerged 2nd-year sweetclover. Close observation of the plants and the soil around them is necessary to detect the weevils. Plant new fields of sweetclover as far away as possible from established stands to minimize infestation by migrating weevils. Sow high-quality, scarified seed no deeper than $25 \mathrm{~mm}$, in a firm, moist seedbed to ensure quick and even emergence of seedlings. Swath the companion crops high. Because 2nd-year sweetclover will usually outgrow weevil damage, applying an insecticide in such fields is rarely necessary. Shallow-cultivate 2nd-year sweetclover that is cut for silage or hay 


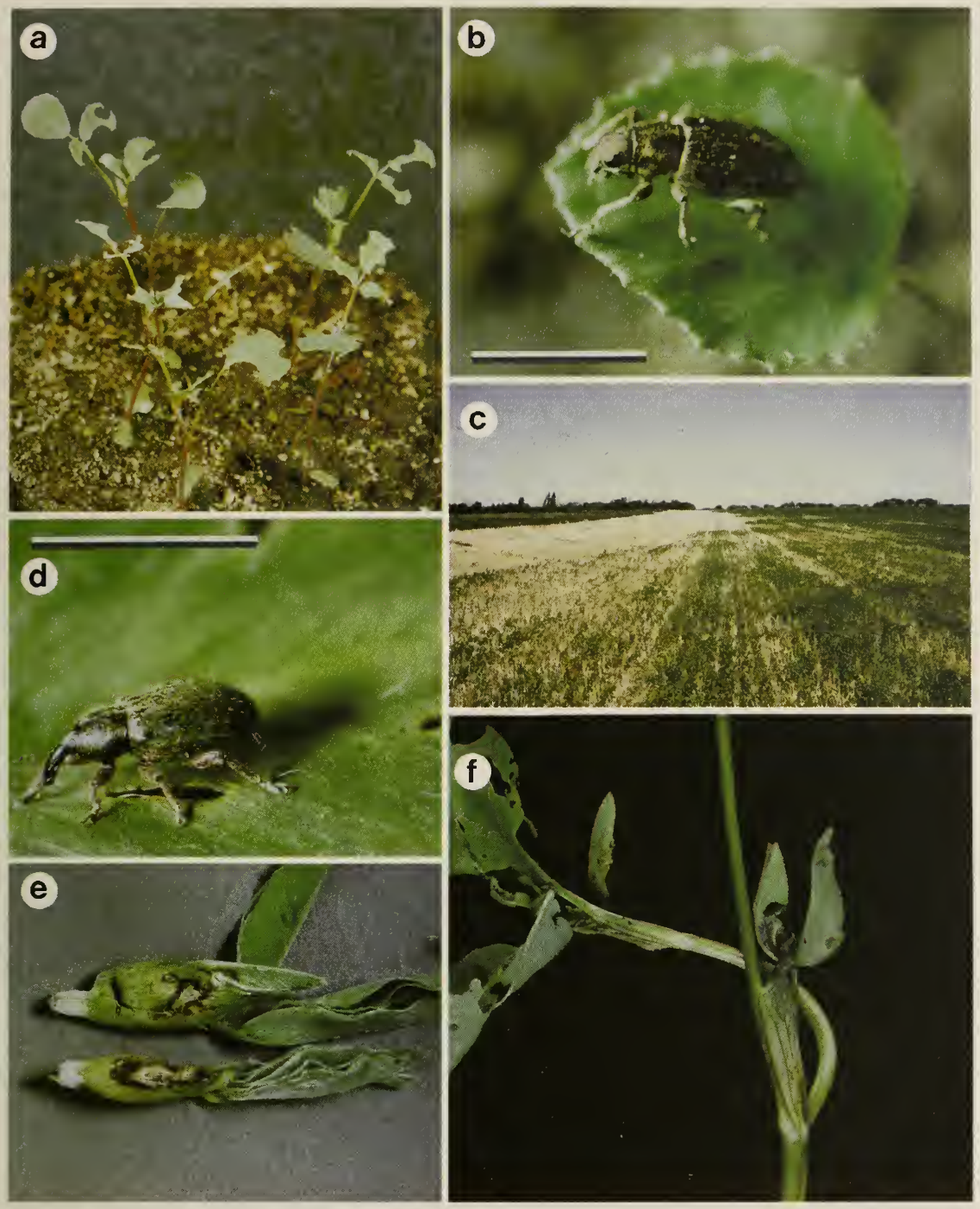

Plate 4a. Sweetclover seedlings showing crescent-shaped feeding notches of sweetclover weevil $b$. Adult sweetclover weevil $c$. Second-year sweetclover stand in spring, showing plant stand loss at field edge caused by sweetclover weevils moving into field and feeding during previous autumn $d$. Lesser clover leaf weevil summer adult $e$. Red clover flower buds injured by older-instar lesser clover leaf weevil larvae $f$. Injury to leaf stipules and folded leaves of red clover caused by young-instar larvae of lesser clover leaf weevil. (Scale: bar $=4 \mathrm{~mm}$ ) 
immediately after the crop has been removed. This tillage will destroy most of the larvae and pupae present in the soil.

Although sweetclover weevil does not reproduce on alfalfa, it feeds on alfalfa when sweetclover is unavailable. Seedling stands adjacent to 2nd-year sweetclover fields are vulnerable to damage from sweetclover weevil.

If the first leaves of seedlings are severely chewed, applying an insecticide to the entire field may be necessary. In the fall, limit plant injury at the margins of 1st-year stands by applying an insecticide along a 20-30 m strip at the field margin.

\section{Insect pests of red clover}

\section{Lesser clover leaf weevil}

Description The adult lesser clover leaf weevil (Hypera nigrirostris (Fabricius)) is a snout beetle, about $4 \mathrm{~mm}$ long (Plate $4 d$ ). Most weevils emerging in the spring are blue-green; some are black. In the summer adults emerging from pupation at first appear light brown, then metallic green. The larva is a grayish to brownish yellow grub with a prominent dark head capsule, reaching $6 \mathrm{~mm}$ in length.

Life cycle Adults overwinter in debris in red clover fields and surrounding areas. They move onto red clover plants when the plants start to grow in the spring. Females lay 200-300 eggs from early May to early June in stems, leaf buds, and stipules. After hatching, the larvae feed for about 3 weeks, at first in leaf bracts and later in flower heads. Larval populations peak in June or July just as the red clover reaches full bloom. Larvae pupate in silken cocoons in flower heads, leaf axils, or in the crowns near the soil surface for about 1 week. Adults start to emerge in mid to late July. They wander and feed for a time before seeking overwintering sites. There is only one generation of lesser clover leaf weevil per year in western Canada.

Damage Both the adults and larvae prefer to feed on red clover but will also feed on alsike, white, and other true clovers. Adults puncture leaves and leaf buds as they feed but do not usually affect forage yields. Larvae feed on leaf and flower buds, perforating leaves (Plate $4 f$ ) and partially or wholly destroying flower heads (Plate $4 e$ ). Sparsely blooming crops indicate larval damage. Flower losses of $40-90 \%$ in single-cut clovers and $30 \%$ in double-cut clovers have been reported in Saskatchewan. Seed losses may be greater in dry years than in wet ones.

Control Several parasites and diseases help reduce weevil numbers. Weather affects the growth and development of clover as well as that of the weevil and its parasites. Rapid growth of red clover generally decreases the severity of weevil damage. Burning of red clover fields in the spring may destroy overwintering adults but may also decrease the numbers of 
predators and parasites. Economic thresholds of lesser clover leaf weevil are not known, but a single weevil larva can destroy an entire flower head before the head emerges. It is very difficult to assess spring populations of lesser clover leaf weevils, but if weevil damage is prevalent in a crop, weevils can be controlled by insecticides. Time the application to kill the adults after most have emerged from overwintering sites but before many eggs have been laid. To be effective the insecticide must thoroughly penetrate the crop canopy.

\section{Clover thrips}

Clover thrips (Haplothrips leucanthemi (Schrank)) are commonly found in red and alsike clover.

Description Adult clover thrips are tiny, slender-bodied, shiny black insects $2 \mathrm{~mm}$ long with four hairy wings. The larvae are $1 \mathrm{~mm}$ long, wingless, and reddish pink; they move slowly.

Several other species of thrips are also found on flowers in forage crops, including the flower thrips (Frankliniella tritici (Fitch)) and the grass thrips (Anaphothrips obscurus (Müller)). The life cycles of all thrips on forage are in general quite similar, although some overwinter as adults and some as larvae, and some species have several generations per year.

Life cycle Clover thrips overwinter as young larvae under the trash and in the soil of clover fields. They develop into adults in the spring. Eggs are laid at the base of flower heads among the developing florets and, after hatching, the larvae move into the florets to feed. There the larvae molt once, feed, and develop into shiny red, mature larvae. They then move down the plant into the soil where they overwinter. There is probably only one generation a year in western Canada.

Damage Both young and adult thrips have rasping-sucking mouthparts with which they scar tissue surfaces and imbibe plant sap. Feeding on young plants results in mottled white patches on leaves, buds, and petioles. In older plants clover thrips feed on flowers and developing seed. If thrips are numerous, their feeding causes rusty brown blotches on the petals and seeds, and possible seed loss. The greatest damage occurs at full bloom. Note that natural petal die back of newly pollinated flowers, and that of unpollinated flowers, resembles damage done by thrips.

Thrips are most likely to infest old clover stands; new stands usually have few thrips in them. Infestations are most severe in years of early spring drought in dryland fields. Economic thresholds are not known, but infestations of less than 50 thrips per clover flower head will not likely affect yield.

Control Thrips are usually kept under control by natural predators that include anthocorid bugs, lady beetles, and predatory thrips. Insecticide control is difficult because of the detrimental effects on pollinators and because the thrips are sheltered inside the flowers. 


\section{Insect pests of white and alsike clovers}

\section{Clover seed weevil}

The clover seed weevil (Tychius picirostris (Fabricius)) occurs across western Canada but is usually an economic pest of only white and alsike clovers grown for seed in British Columbia.

Description The adult clover seed weevil has a long, slightly curved beak, is slate gray to black, and is about $2.5 \mathrm{~mm}$ long. It is the smallest weevil commonly found in clover. The larva is a grayish white grub with a brown head capsule, reaching $3.2 \mathrm{~mm}$ in length at maturity.

Life cycle Adult weevils overwinter in leaf litter and debris in or near previously infested fields. When the clover starts to bloom, overwintering adults migrate into the crop and feed on the flower heads. Females lay their eggs inside florets and developing pods. The larvae feed on the seeds for about 2 weeks then drop to the ground to pupate. The next generation adults appear in late July and August, feeding on clover foliage and on developing seed pods until they seek overwintering sites by late summer. There is one generation per year.

Damage Feeding by both larvae and adults decreases the yield of clover seed. Adult weevils puncture the petals and the base of the florets to feed on the reproductive parts and to lay eggs in the immature seedpods. Larvae feed on the developing seeds inside the seedpods.

Control Control clover seed weevil by applying insecticide at the proper time. Apply the insecticide after the adults migrate to the clover fields in spring, but before the females start to lay eggs. This period is usually between the withering of the first blossoms and the drying of the complete heads.

\section{Clover leaf weevil}

Description Clover leaf weevils (Hypera punctata (Fabricius)) resemble alfalfa weevils, to which they are closely related. They are from 6 to $13 \mathrm{~mm}$ long, with prominent snouts and with light-colored stripes on their backs. Young larvae resemble alfalfa weevil larvae but are slightly larger and less green. Mature larvae are about $13 \mathrm{~mm}$ long, light green to yellowish green, with a pale stripe down the centre of their backs. Clover leaf weevils are found on most clovers and alfalfa. They also feed on cereals, many common weeds, and ornamental plants.

Life cycle These weevils overwinter mainly as immature larvae in the soil near plant crowns. Larvae complete their development on foliage in the spring and reach maturity by May or June. They pupate in net-like cocoons near the soil surface. Adults emerge in 1-2 weeks. They are inactive in the summer, then mate and lay eggs on or near the plants during September 


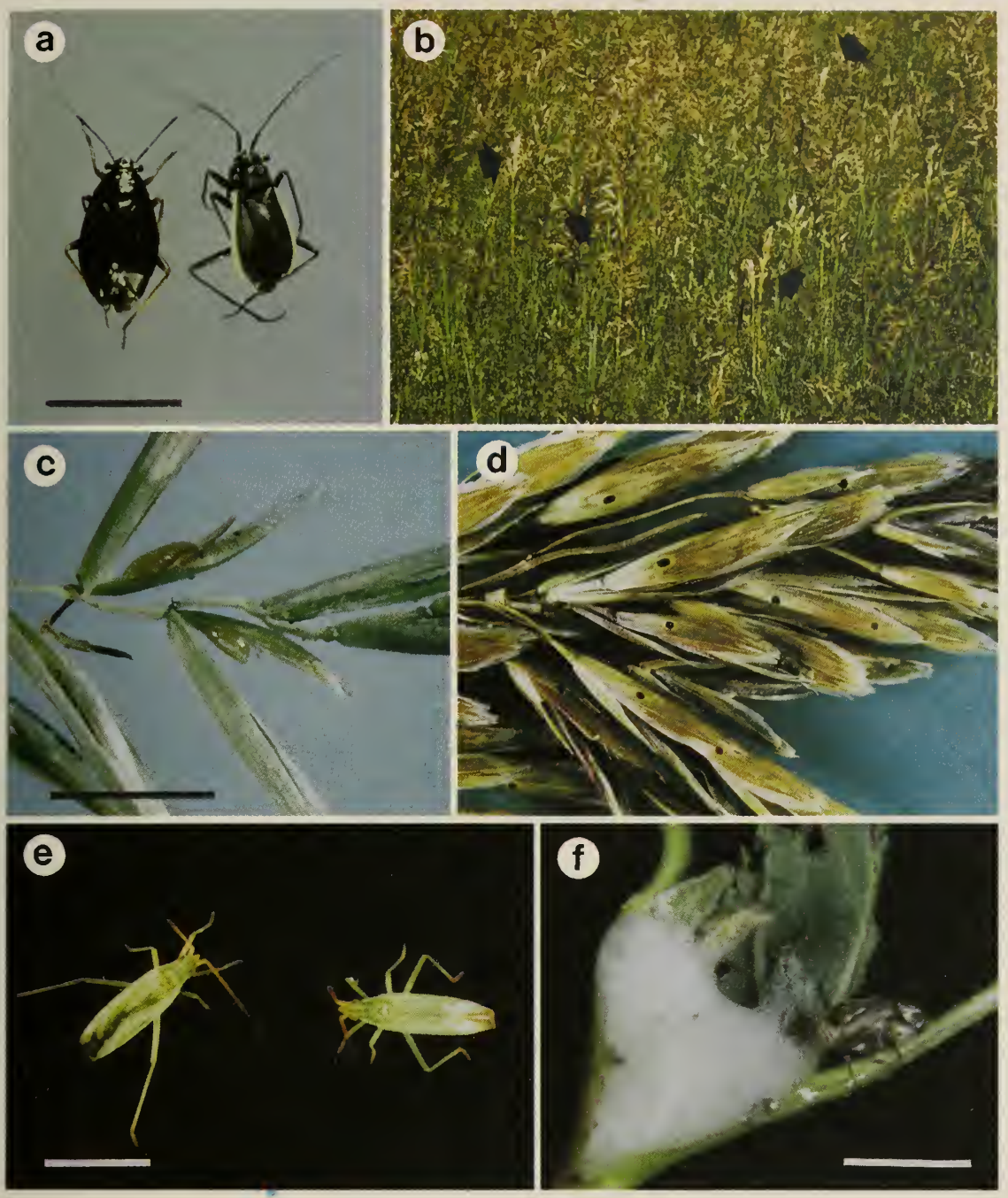

Plate 5a. Grass plant bugs: Capsus simulans (Stål) (left) and Labops hesperius Uhler (right) $b$. Bromegrass field with bleached seed heads indicative of silvertop (arrows) c. Bromegrass seed midge larvae in a bromegrass seed head $d$. Bromegrass panicle; florets have exit holes made by a wasp parasite of bromegrass seed midge $e$. Adults of a green grass bug, Trigonotylus coelestialium (Kirkaldy) $f$. A spittlebug nymph surrounded by spittle. (Scale: bar $=4 \mathbf{m m}$ ) 
and October. Most of the eggs hatch in the fall. There is one generation per year.

Damage Both larvae and adults are foliage feeders. Their damage is similar to that of alfalfa weevil. Although clover leaf weevils are present in legume fields each year in western Canada, they cause only localized damage. Damage is most noticeable in the spring and seems to be most severe in cool, dry springs.

Control Populations of clover leaf weevil are usually kept in check by a fungus disease. Damage to forages occurs when weather conditions are unfavorable for fungal growth. When damaging outbreaks occur, insecticides for control of alfalfa weevil will also control populations of clover leaf weevil.

\section{Insect pests of grasses}

Few insects are a common threat to native or cultivated grass crops in western Canada. Grasshoppers, as described earlier, are the most prevalent insect pests in grass seed crops.

\section{Bromegrass seed midge}

Description Adult bromegrass seed midges (Contarinia bromicola (Marikovskij \& Agafonova)) are small flies about the size of mosquitoes; they are similar in appearance (although not in color) to the wheat midge (Sitodiplosis mosellana (Géhin)), which is orange. The golden yellow, full-grown larvae are maggot-like and are found in the bromegrass floret (Plate $5 c$ ). This midge does not attack other grasses.

Life cycle The midge overwinters as a larva or pupa in bromegrass seed hulls on the soil surface. Larvae pupate in spring, and adults emerge about the time the grass is heading out. There are usually two peaks in adult emergence, which suggests either that there are two generations per year or that emergence occurs over an extended time. Females lay their eggs in developing flower heads, and, when these hatch, the larvae feed on the flower ovaries. Later, egg laying occurs on older flowers, and the emerging larvae feed on very young seeds. The larvae enter diapause or pupate at the tips of seed hulls, which drop to the ground at harvest.

Damage The bromegrass seed midge is a pest only of bromegrass grown for seed. It causes low seed yields by destroying florets and by increasing seed shattering. In some areas seed losses of more than $50 \%$ have been reported. Midge damage to bromegrass can sometimes be detected by the presence of tiny exit holes in the florets (Plate $5 d$ ). These are caused by a wasp parasite of the midge. Parasitism by the wasp may reach more than $90 \%$. The presence of wasp exit holes, although it is used as a measure of the 
infestation of bromegrass by the midge, underestimates the amount because not all the midges will have been parasitized. Damage is frequently more severe in old than in young stands, in wet years, or in areas of high humidity.

Control Postharvest or spring burning of grass fields provides some midge control. Destroying or early mowing of patches of volunteer bromegrass also aids in reducing midge numbers. Economic thresholds for bromegrass seed midge are not known. Treating with insecticide just prior to, or at, head development can reduce numbers of the midge but will also kill its parasites. Timing of application is essential for effective control, but damage levels may not justify the costs. There is some indication that meadow bromegrass is affected less severely than smooth bromegrass.

\section{Grass plant bugs}

Several species of grass plant bugs (Stenodema spp., Irbisia spp., Capsus spp., Trigonotylus spp., Labops spp., and others) infest grasses and small grains across western Canada. They are related to but are not the same as the plant bugs that infest alfalfa.

Description The adults of Trigonotylus (Plate 5e) and Stenodema species are pale green, have slender bodies 5-9 $\mathrm{mm}$ long and 1-3 mm wide, and have long slim legs and antennae. Irbisia and Capsus bugs are black; Irbisia adults are about $6 \mathrm{~mm}$ long and $2 \mathrm{~mm}$ wide, whereas Capsus bugs (Plate $5 \mathrm{a}$ ) are slightly shorter and broader. Labops are small $(4 \mathrm{~mm})$ black bugs with yellow areas on the face and wing edges (Plate $5 a$ ). The nymphs appear generally the same as the adults but are smaller and wingless.

Life cycles The life cycles of most of these species are not well known but are probably similar to those of the plant bugs on alfalfa. The species overwinter as adults or eggs in litter and debris in grass fields. Females probably lay eggs inside grass stems. The eggs hatch into nymphs that complete their development in about 1 month.

Damage Grass plant bugs pierce the stems of grasses and suck plant sap. The point of injury on the stem becomes shriveled and constricted, preventing the passage of nutrients beyond the point of injury. Damaged seedstalks are dead above the highest or second-highest node and can be relatively easily pulled out of the leaf sheath, whereas the rest of the plant appears green and healthy. This condition, known as silvertop, occurs in grasses such as Kentucky bluegrass, bromegrass, crested wheatgrass, fescues, intermediate wheatgrass, and timothy. Silvertop is most noticeable at heading. The damage appears as white heads scattered among the normal green ones (Plate $5 b$ ). Although the exact causes of silvertop are not known, treatment of grass seed fields with insecticide has decreased its incidence. 
Grass plant bugs are not considered a pest of grass forage production, although the extraction of plant sap by a severe infestation may decrease the vigor of plants.

Control The burning of grass fields after harvest decreases the numbers of grass plant bugs. Burning of fescue is not practical in the Peace River region because of the likelihood of damage to the next year's seed crop. If insecticides are used, apply them before the heads emerge from the leaf sheath. Note: Some of the larger stemmed grasses, including bromegrass and intermediate wheatgrass, are damaged by stem-boring insects such as wheat stem maggot (Meromyza americana Fitch). Symptoms of plant injury are similar to those of silvertop. The larvae feed in the seed stalk above the last node, cutting off the stem within the sheath and causing the seed head to be sterile. When full-grown the larvae chew their way out of the leaf sheaths. The jagged exit holes are easily noticed and are one way of distinguishing between damage to seedheads by grass plant bugs and by stem maggots.

\section{Cereal aphids}

Cereal aphids (Macrosiphum avenae (Fabricius), Schizaphis graminum (Rondani), and others) have life cycles and injurious effects similar to those of legume aphids but are restricted to small grains and wild and cultivated grasses as their hosts. Average infestations of 50 English grain aphids (Sitobion avenae (Fabricius)) per head from boot to early dough stage can reduce kernel weight of wheat, but economic thresholds for cereal aphids on grass crops have not been determined. When aphids become numerous, they are attacked by many species of parasites and predators. As grains and grasses mature, their quality as food for aphids declines and aphid populations on them will decrease rapidly. Therefore, it is not usually economical to treat infestations of any cereal aphids at the dough stage and later, because further yield loss rarely occurs.

\section{Russian wheat aphid}

Within 2 years the Russian wheat aphid (Diuraphis noxia (Mordvilko)) spread from the southern United States to the Canadian border. In 1988 this aphid caused economic losses to fall-seeded cereals in southern Alberta and Saskatchewan. Although the Russian wheat aphid is a pest of springand fall-seeded cereals, it can also persist on cool-season grasses such as bromegrass, crested wheatgrass, intermediate wheatgrass, and tall wheatgrass. These grasses provide potential overwintering sites for the aphid between cereal crop cycles.

Description The Russian wheat aphid is a spindle-shaped, yellowish green to greenish gray aphid about $2 \mathrm{~mm}$ long (Plate $2 a$ ). It has short antennae and a small projection above the tail, giving the tail a forked appearance when viewed from the side. 
Life cycle The aphid is remarkably cold tolerant. It first overwintered in Canada in 1989-1990 but may not do so every year. It can be carried in on southerly air currents, as are numerous other pests. To date neither males nor eggs have been found in North America. Colonizing females are winged; if a satisfactory host is found several generations of wingless females are produced. These aphids live from 5 to 7 weeks, with each female producing about 30-50 young. Depending on temperature, the nymphs reach reproductive maturity in 1-3 weeks. When conditions become unsuitable, such as when the aphids are crowded or when the host plant matures, winged forms develop and move in search of new host plants.

Damage Characteristic symptoms of Russian wheat aphid feeding on wheat include rolling inward of the leaf margins, twisting and spiraling of the leaf blade, and longitudinal streaking and discoloration of the leaves (Plate $2 b$ ). Streaking may be white, yellow, red, or purple. Infested patches appear flattened and drought-stricken. Seed heads may become trapped in the flag leaf, so that its appearance resembles a fish hook. Individual florets or, in extreme cases, the entire head may be sterile. Some or all of these symptoms may be absent in other host species, including some of the grasses. It is not known if symptomless hosts suffer losses in yields.

Even light infestations can cause considerable damage, because the aphid injects a toxin into the plant as it feeds. High populations can reduce cereal seed yields by more than $80 \%$. This aphid has also been implicated as a vector of several cereal diseases, including brome mosaic virus. The effect of Russian wheat aphid feeding on crops used as forage is unknown.

Control Destroy volunteer cereals. There are many natural enemies of aphids in western Canada, but, because the Russian wheat aphid is a new pest, it will be several years before their effect on the aphid is known. Insect species that feed upon the Russian wheat aphid in its country of origin are being introduced to the prairies. Because the aphid feeds in curled leaves, insecticide control is difficult. However, insecticides have been successfully used to minimize yield losses in cereals. More than one application of insecticide may be necessary. Economic thresholds depend upon the plant stage at infestation. Based on American data, suggested thresholds are $5-10 \%$ of plants infested prior to the boot stage, $10-20 \%$ of plants infested from boot to early flowering, or more than $20 \%$ of plants infested after flowering.

\section{Spittlebugs}

Spittlebugs (Cercopidae) occasionally cause heavy losses to grass seed yields in the Peace River region. They are common on legume forage crops and many grasses, particularly Kentucky bluegrass and fescues.

Description Spittlebug adults are mottled tan, green, to grayish brown, leafhopper-like insects about 5-8 $\mathrm{mm}$ long, with their wings folded tent-like above their backs. They are active flyers and hoppers. The 
nymphs live and feed inside white, frothy masses attached to the grass stems and leaves just above the crown (Plate $5 f$ ).

Life cycle Spittlebugs overwinter as eggs in or near host fields. Hatching occurs in early spring and nymphs move to green plants and form spittle. Nymphs molt five times and become adults by the end of June. During the summer new adults become very noticeable as they migrate in search of food. In the fall, the females lay eggs and die.

Damage Nymphs and adults suck plant sap. Infested plants are stunted and generally less vigorous than uninfested plants. Seedstalks can become partially trapped by the leaf sheath, turn white, and die. As they feed, spittlebugs inject toxins that are translocated throughout the plant. Therefore, all seed stalks from the same tuft may die even though not all have been fed upon.

Control Spittlebug eggs are killed by fall burning or plowing. Insecticides, such as those used for silvertop control, can be effective against spittlebug if applied within 1 week after the eggs hatch. Later applications may give inadequate control because the spittle masses protect the insects.

\section{European skipper}

The European skipper (Thymelicus lineola (Ochsenheimer)) is a pest of timothy grass in Ontario, Quebec, and Prince Edward Island. It has recently been found in Manitoba and British Columbia. Larvae prefer to feed on timothy but also feed on the leaves of several other grasses, including perennial ryegrass, meadow fescue, orchardgrass, and quack grass.

Description Adult skippers are bright orange butterflies with narrow, dark wing borders and thin, black lines along main veins (Plate 2c). Their wing span is about $25 \mathrm{~mm}$. Larvae are greenish, with two white stripes extending from their heads along their backs. Fully grown larvae are about $25 \mathrm{~mm}$ long.

Life cycle European skippers overwinter in timothy and other grass fields as first-instar larvae in the shells of the eggs. Larvae begin to emerge from the egg shells in early May. They crawl up the grass blades and form tunnels by drawing the edges of the leaves together and tying them with silk. They develop through five instars and pupate on leaf debris, on the underside of leaves, or, if populations are high, on the bare soil. Adult butterflies emerge by early July, mate, and lay eggs in vertical rows on the inside of the leaf sheaths of grasses, chiefly timothy. These eggs develop into larvae by late July, but the larvae remain within the egg shell until the next spring, so that there is only one generation per year. 
Damage Larvae, the most damaging of which are the fourth and fifth instars, chew on the grass blades on either side of their tunnels (Plate $2 f$ ). If populations are high, many older larvae do not make leaf tunnels but feed on the exposed surface of the leaf. They can completely defoliate a field. If defoliation is extensive, larvae may also feed on developing seed heads. Defoliation is most severe by early to mid June. Legume flowers are preferred nectar sources for the butterflies. Therefore, mixing legumes and timothy will aggravate the problem because it provides an abundance of food and egg-laying sites in the same field.

Control Because eggs can survive in baled hay, take care when importing timothy hay from skipper-infested areas. Eggs can also survive in association with seed and screenings, so that all timothy seed screenings from areas of skipper infestation should be destroyed. If larvae numbers reach damaging levels, insecticides containing Bacillus thuringiensis Berliner are effective in controlling them. Egg laying can be greatly reduced by removing the cut grass as soon as possible after cutting. Skipper numbers can also be reduced in pastures containing timothy by heavy grazing in a rotation of short duration.

\section{Grass thrips}

Several species of thrips (Thysanoptera) occur on grasses in western Canada.

Description Adults are tiny, slender-bodied insects $0.5-5 \mathrm{~mm}$ long (Plate $2 d)$. They may or may not have wings. If present, there are four very long and narrow wings, fringed with fine hairs. Young larvae are very small, slender, and somewhat worm-like (Plate $2 e$ ).

Life cycle Most grass thrips overwinter as adults in grass and debris in shelterbelts and bluffs. They become active early in the spring. Eggs are usually laid on leaves and flower heads. Young thrips are relatively inactive and remain close to the place where they were born. There are generally several generations of thrips a year. Often older grass stands harbor more thrips than younger stands.

Damage Thrips destroy plant tissue by rasping on plant surfaces, which causes the growing points to become shriveled, malformed, or blasted. Both adults and larvae feed on the protected portions of the plant such as the terminal leaf sheath and flower parts, where damage is often concentrated. Thrips cause reduced seed set in bromegrass. The grass thrips (Anaphothrips obscurus (Müller)) may cause silvertop.

Control Insect predators are an important factor in the control of thrips. Although damage to grasses such as fescue and bromegrass have been reported, to date there is no evidence that grass thrips are of general economic importance in western Canada. Therefore, applying insecticide is 
rarely warranted. Removal of old grass growth in the fall or spring is recommended.

\section{Other pests of legume and grass crops}

Many other insects can be economic pests in certain localities in certain years. Alfalfa loopers (Autographa californica (Speyer)), alfalfa caterpillars (Colias eurytheme Boisduval), clover cutworms (Discestra trifolii (Hufnagel)), leafhoppers, woolly bear caterpillars (Grammia blakei (Grote)), false chinch bugs, northern false chinch bugs (Nysius niger Baker), wireworms and many others can occasionally reach outbreak proportions. Growers should diligently inspect fields so that, if the potential for insect damage exists, they can identify the pest and take remedial action.

Damage from all plant-feeding insects is increased when the crop is stressed by such conditions as drought or nutrient deficiency. Often the best defense against insect damage is a healthy, rapidly growing crop.

\section{Beneficial insects}

Probably most insect species in crops either have no economic impact or aid in controlling harmful insects. Beneficial insects fall into two groups: predators and parasites.

Predators are insects that actively search out and eat other insects to complete their development. Both immature and adult life stages of insects such as lady beetles (Plate $6 c, d$ ) are predacious, whereas only the larvae of insects such as syrphid flies (Plate $6 h$ ) attack other insects, with adults (Plate $6 g$ ) being pollen and nectar feeders. Predators can consume considerable numbers of prey. Some lady beetle larvae consume 300-600 aphids during their development, whereas adults can eat 2000-3000 aphids. Beneficial predators commonly found in legume and grass fields include immature and adult lady beetles (Plate $6 c, d$ ), minute pirate bugs (Orius tristicolor (White)) (Plate 6f), lacewings (Plate $6 i, j$ ), damsel bugs, bigeyed bugs, ambush bugs, assassin bugs, larvae of syrphid flies (Plate 6h), and spiders.

Plate $6 a$. Leafcutting bee on an alfalfa raceme $b$. Sampling an alfalfa field for insects using a sweep net $38 \mathrm{~cm}$ in diameter $c$. Seven-spotted lady beetle adult feeding on bird cherry oat aphids $d$. Seven spotted lady beetle larva feeding on a bird cherry oat aphid $e$. Ichneumonid wasp parasite of crop pests $f$. Minute pirate bug adult $g$. Syrphid fly adult feeding on flower nectar $h$. Syrphid fly larva $i$. Adult lacewing $j$. Lacewing larva feeding on an English grain aphid. $($ Scale: bar $=4 \mathrm{~mm})$ 

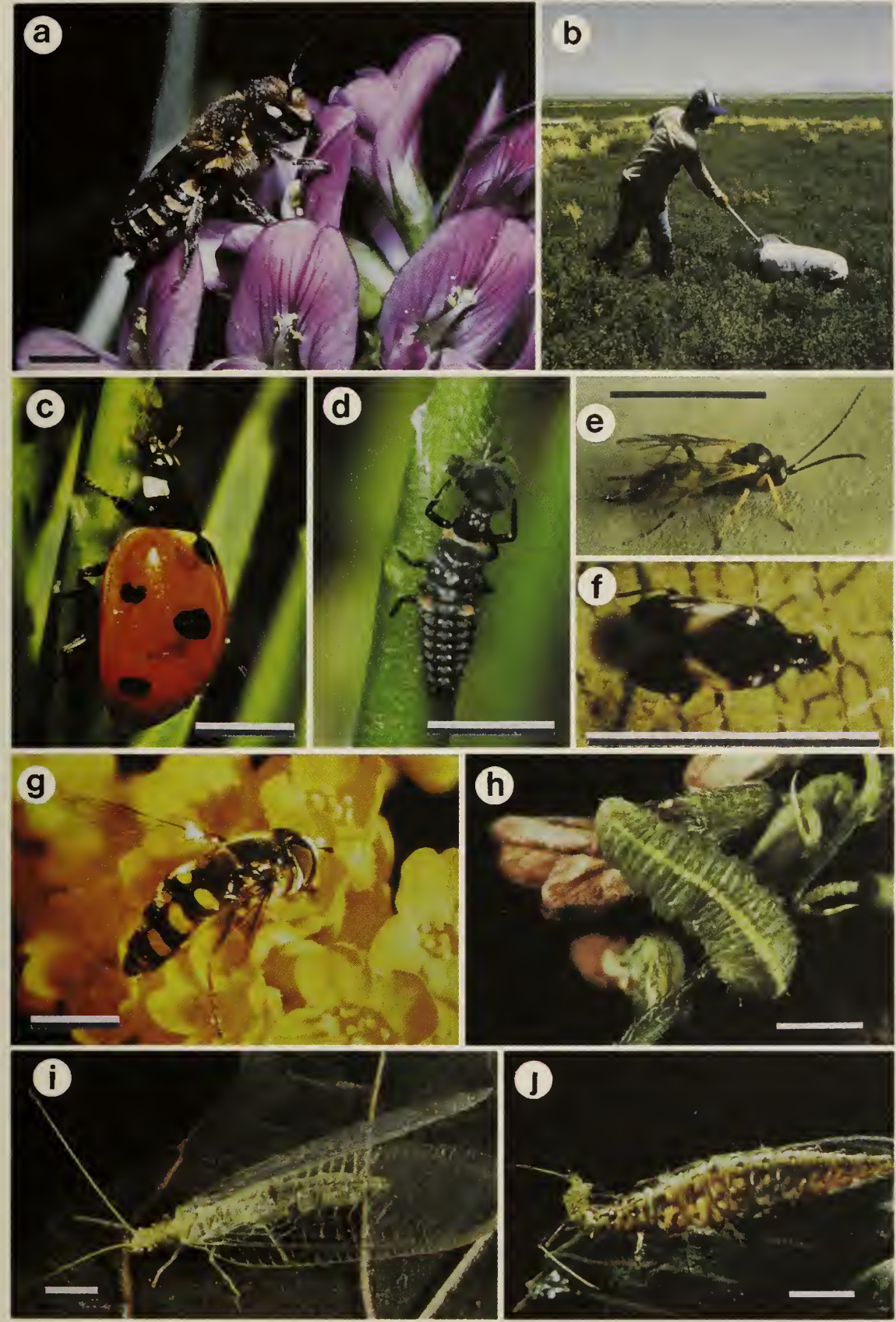
Insect parasites lay their eggs in or near insect hosts, and the larvae develop inside or on the hosts. A parasitic larva feeds on the tissues of the host insect and normally kills it just before the parasite is completely developed. There is usually one parasite per host insect. Commonly larvae are parasitic whereas the adult stage is free-living. Common insect parasites include ichneumonid (Plate $6 e$ ) and braconid wasps, and tachinid flies. Occasionally, beneficial insects, such as damsel bugs and parasites of aphids, are themselves parasitized.

\section{Precautions on the use of insecticides}

At the time of writing, several insects discussed in this bulletin have no insecticides registered for their control in western Canada, even though it is mentioned that insecticides may decrease their populations. This may change with time and more research. Never use an insecticide, a formulation, or a dosage that is not registered for a particular use as set forth on the insecticide container label. Insecticides recommended in control bulletins issued by provincial agencies have been tested and found effective. Most recommendations for treating forage crops include a waiting period between treatment and harvest or grazing; always observe that wait.

Seed production of alfalfa and clovers is dependent upon pollination by leafcutting bees (Plate $6 a$ ), honey bees, bumble bees, and other native bees. Pesticide hazard to bees varies with formulation, dosage, and weather conditions both during and after application. Emulsifiable formulations generally have a shorter residual toxicity to bees than either wettable powders or flowable formulations and are less easily acquired from the plant when bees are foraging. Abnormally cool weather following application can result in pesticide residues lasting up to 20 times longer than in warm weather. If warm temperatures occur during late evening or early morning after spraying, bees may actively forage in the treated crop longer and may receive greater exposure to the insecticide. Apply insecticides in calm weather so that spray drift is minimal. Ground spraying causes less drift than aerial spraying. Notify beekeepers in the area ahead of time that you intend to spray.

Table 1 provides data on the toxicity to bees of commonly used insecticides. These hazard data were not developed under western Canadian conditions and should be used as a guideline only. This information does not imply that any insecticide is recommended. Above all, read the container label and follow its instructions carefully. 


\begin{tabular}{|c|c|c|c|c|}
\hline \multirow[b]{2}{*}{ Insecticide } & \multirow[b]{2}{*}{$\begin{array}{l}\text { Bee } \\
\text { toxicity }^{1}\end{array}$} & \multirow{2}{*}{$\begin{array}{l}\text { Residue } \\
\text { hazard (days) }\end{array}$} & \multicolumn{2}{|c|}{ Conditions for application ${ }^{3}$} \\
\hline & & & $\begin{array}{l}\text { Leafcutting } \\
\text { bees }\end{array}$ & $\begin{array}{l}\text { Honey } \\
\text { bees }\end{array}$ \\
\hline acephate & $\mathrm{M}-\mathrm{MH}$ & 3 & A & A \\
\hline azinphos-methyl & $\mathrm{M}-\mathrm{VH}$ & $3-5$ & A & A \\
\hline B. thuringiensis & none & none & $\mathrm{C}$ & $\mathrm{C}$ \\
\hline bendiocarb & & $<1$ & A & A \\
\hline carbaryl & $\mathrm{M}-\mathrm{VH}$ & $<1-7$ & A-B & $\mathrm{A}-\mathrm{C}$ \\
\hline carbofuran & VH & $5-10$ & A & A \\
\hline carbophenothion & M & $<1$ & B & B \\
\hline chlorfenvinfos & $\mathrm{L}$ & - & - & $\mathrm{C}$ \\
\hline chlorpyrifos & $\mathrm{H}$ & $4-7$ & A & A \\
\hline cypermethrin & $\mathrm{H}$ & $<3$ & A & A \\
\hline deltamethrin & $\mathrm{H}$ & 1 & B & B \\
\hline diazinon & $\mathrm{H}$ & 2 & A & A \\
\hline dichlorvos & $\mathrm{H}$ & - & A & A \\
\hline dicofol & $\mathrm{L}$ & none & $\mathrm{C}$ & $\mathrm{C}$ \\
\hline dimethoate & $\mathrm{MH}-\mathrm{VH}$ & $3-7$ & A & A \\
\hline disulfoton & M & 1 & $\mathrm{C}$ & $\mathrm{C}$ \\
\hline endosulfan & L-MH & $1-3$ & $\mathrm{~A}$ & $\mathrm{~B}$ \\
\hline fensulfothion & VH & - & - & A \\
\hline fenthion & VH & - & - & A \\
\hline fenvalerate & $\mathrm{H}$ & 1 (honey bees) & A & B \\
\hline lindane & $\mathrm{M}-\mathrm{MH}$ & - & - & A \\
\hline malathion & L-MH & $1-7$ & A & $A-B$ \\
\hline methamidophos & $\mathrm{H}$ & 1 & A & A \\
\hline methidathion & $\mathrm{H}$ & $1-7$ & A & A \\
\hline methomyl & $\mathrm{H}$ & $<1-1.5$ & B & $\mathrm{C}$ \\
\hline methoxychlor & $\mathrm{L}$ & $<1$ & B & $\mathrm{C}$ \\
\hline mevinphos & $\mathrm{M}-\mathrm{H}$ & $0.5-1.5$ & A & A \\
\hline naled & $\mathrm{MH}-\mathrm{VH}$ & $1-3$ & A & A \\
\hline oil sprays & & - & - & B \\
\hline oxydemeton-methyl & $\mathrm{M}-\mathrm{H}$ & $<1$ & $\mathrm{C}$ & $\mathrm{C}$ \\
\hline permethrin & & $1-5$ & A & A \\
\hline phosmet & $\mathrm{MH}-\mathrm{VH}$ & $<3$ & A & A \\
\hline pirimicarb & - & $<1$ & A & A \\
\hline propoxur & VH & 1 & A & A \\
\hline pyrethrum & $\mathrm{L}$ & - & $\mathrm{C}$ & $\mathrm{C}$ \\
\hline rotenone & $\mathrm{L}$ & - & C & $\mathrm{C}$ \\
\hline temephos & M & 1 & $\mathrm{C}$ & $\mathrm{C}$ \\
\hline tetradifon & $\mathrm{L}$ & $<1$ & B & $\mathrm{C}$ \\
\hline trichlorfon & $\mathrm{L}$ & $<1$ & $\mathrm{C}$ & $\mathrm{C}$ \\
\hline
\end{tabular}

1 Poisonous effect of the insecticide on bees that contact treated foliage immediately after it is sprayed. $\mathrm{L}=$ low; $\mathrm{M}=$ moderate; $\mathrm{H}=$ high; $\mathrm{MH}=$ moderately high; $\mathrm{VH}=$ very high; - = no verified information available.

2 The length of time after application that toxic residue remains on foliage.

3 Conditions under which the insecticide may or may not be applied:

A - Do not apply at any time to crops in bloom.

B - Apply only in the evening when bees are not foraging.

C - Apply in the evening, at night, or in the morning, when bees are not foraging. 


$$
\begin{aligned}
& \text { Recycled } \\
& \text { Paper }
\end{aligned}
$$

